\title{
Factors Affecting Junior High School Students' Interest in Physics ${ }^{1}$
}

\author{
Ricardo Trumper ${ }^{2,3}$
}

\begin{abstract}
We report the results of a study on students' interest in physics at the end of their compulsory schooling in Israel carried out in the framework of the ROSE Project. Factors studied were their opinions about science classes, their out-of-school experiences in physics, and their attitudes toward science and technology. Students' overall interest in physics was "neutral" (neither positive nor negative), with boys showing a higher interest than girls. We found a strong correlation between students' "neutral" interest in physics and their negative opinions about science classes. These findings raise serious questions about the implementation of changes made in the Israeli science curriculum in primary and junior high school, especially if the goal is to prepare the young generation for life in a scientific-technological era. A more in-depth analysis of the results led us to formulate curricular, behavioral, and organizational changes needed to reach this goal.
\end{abstract}

KEY WORDS: interest; junior high school students; physics.

\section{INTRODUCTION}

As noted by Osborne et al. (2003), "the investigation of students' attitudes towards studying science has been a substantive feature of the work of the science education research community for the past 30-40 years" (p. 1049). Its importance is emphasized by a persistent decline in post-compulsory high school science enrollment over the last two decades which has generated concern in many countries, including the UK (Smithers and Robinson, 1988), Australia (Dekkers and DeLaeter, 2001), Canada (Bordt et al., 2001), India (Garg and Gupta, 2003), Japan (Goto, 2001), the United States (National Sci-

\footnotetext{
${ }^{1}$ ROSE (The Relevance of Science Education) is an international project with about 40 participating countries. ROSE is organized by Svein Sjoberg and Camilla Schreiner at The University of Oslo and is supported by the Research Council of Norway. Reports and details are available at http://www.ils.uio.no/english/rose/.

${ }^{2}$ Faculty of Science and Science Education, Haifa University, Mount Carmel, Haifa 31905, Israel; e-mail: rtrumper@research. haifa.ac.il

${ }^{3}$ Present address: Kibbutz Hahoterim, Doar Na Hof Hacarmel 30870, Israel.
}

ence Foundation, 2002), and every country in the European Union (Commission of European Communities, 2001). Students' increasing reluctance to choose science courses, and physical science courses in particular, in their final years of secondary education has important implications not only for the continuity of scientific endeavor but also for the scientific literacy of future generations. As a result, development of positive attitudes towards science, scientists, and learning science, which has always been a constituent of science education, is increasingly a subject of concern.

Many science educators attribute great importance to the affective domain (Baker and Doran, 1975; Gardner, 1985, 1998; Oh and Yager, 2004; Schibeci, 1984; Sjoberg, 2002). Shulman and Tamir (1973) argued that the affective outcomes of science instruction are at least as important as their cognitive counterparts. The affective domain is characterized by a variety of constructs such as attitudes, preferences, and interests. Different researchers' definitions of these constructs vary and consequently may be confusing. As reported extensively in the literature, students' originally positive attitudes toward 
science subjects change markedly in the upper grades, especially in chemistry and physics (Graber, 1993). Simpson et al. (1994) published an extensive review of students' attitudes toward different science subjects. Generally, a negative attitude toward a given subject leads to lack of interest and, when subjects can be selected, as in senior high school, to avoiding the subject or course. Furthermore, a positive attitude toward science "leads to a positive commitment to science that influences lifelong interest and learning in science" (Simpson and Oliver, 1990, p. 14). This is one reason why major science education reform efforts have emphasized the improvement of students' attitudes. For instance, Project 2061, a multiple-year project in science education, suggests that "science education should contribute to ... the development in young people of positive attitudes toward learning science" (American Association for the Advancement of Science, 1990, p. 184).

Several studies have identified a number of factors affecting students' attitudes towards science in general. These can be largely categorized as gender, personality traits, structural variables, and curriculum variables. Of these, the most significant is gender for, as Gardner (1975) stated "sex is probably the most important variable related to pupils' attitudes to science" (p. 22). Many studies (e.g., Francis and Greer, 1999; Jones et al., 2000; Menis, 1983; Sjoberg, 1983, 2000a,b; Weinburgh, 1995) have reported that males have more positive attitudes toward science than females, while others found no statistically significant gender differences (Selim and Shrigley, 1983). Kahle and Meece (1994) published a wide-ranging review of the gender issues related to students' attitudes to science subjects. Ormerod and Duckworth (1975) indicated the importance of distinguishing between the physical and biological sciences in respect of gender differences in attitudes toward science. Gardner (1974), in a review of the relation between gender differences and achievement, attitudes, and some personality traits of science students, stated that there are "clear differences in the nature of 'boys' and 'girls' scientific interests, boys expressing relatively greater interest in physical science activities, while girls are more interested in biological and social science topics" (p. 243). More recently, Osborne et al. (2003) showed "that there is still a bias against physical sciences held by girls, suggesting that at an individual level the overwhelming majority of girls still choose not to do physical science as soon as they can" (p. 1064). Their comprehensive literature survey shows that one of the main motivators for gender-related research in science education is the fact that there are few girls in technical and science-related occupations and that more qualified personnel are needed. Physics in the upper secondary school is a kind of "gate-keeper" for science, technology, and medical studies.

Israel took part in the Second International Science Study (SISS) in 1983-1984. In this study, 82\% of the 10 -year-olds and $66 \%$ of the 14 -year-olds said that science was interesting. Among the 17-year-old students who elected to study science for the matriculation examination, $72 \%$ found the study of biology interesting, while only $48 \%$ found the study of physics interesting (Tamir et al., 1988). Shemesh (1990) found that Israeli junior high school girls tended to be more interested in languages, social studies, and humanities, while boys were more interested in the natural sciences and technology. Furthermore, boys' interest in science and technology increased with age, while older girls became less interested. Likewise, the U.S. Department of Education (1997) reported that while male and female 7th and 10th graders have similar positive attitudes toward science, high school seniors show a greater difference in these attitudes. Unfortunately, these less favourable attitudes of females often translate into less interest in science careers. Ironically, "young women begin to lose interest in science even when they perform as well, or even better, in this subject as their male classmates" (Catsambis, 1995, p. 252).

According to Gardner and Tamir (1989a):

\begin{abstract}
The term 'interest' usually refers to preference to engage in some types of activities rather than others. An interest may be regarded as a highly specific type of attitude: When we are interested in a particular phenomenon or activity, we are favorably inclined to attend to it and give time to it. (p. 410)
\end{abstract}

Hoffman (2002) distinguished between general interest in physical matters and interest in physics as a school subject. In this study, we deal with students' interest in physics as a school subject, that is, a combination of individual interest in physics, a short-term interest in certain physics topics produced by the interestingness of physics instruction in the sense of situational interest (Hidi and Andersen, 1992), and the social climate in physics classes. The combination of factors determining interest in physics as a school subject varies from one student to another. Hoffman (2002) states that "As girls have less pre- and out-ofschool experience with physics, the interestingness of physics instruction seems to be more important for girls' interest development than for boys"' (p. 449). 


\section{LEARNING PHYSICS IN ISRAEL}

The study of preferences and interests in physics is of vital importance in Israel because the Ministry of Education has promoted major changes in the study of science in primary and secondary schools. New science curricula were introduced more than 5 years ago in order to "strengthen, deepen and improve the learning of mathematics, science and technology throughout the educational system, as a means of preparing the new generation for life in a scientifictechnological era" (Tomorrow 98, 1992, p. 9). The recommendations of the Tomorrow 98 Report are in line with the worldwide trend towards the introduction of science, technology, and society (STS) interactions in science education. As a consequence, today in Israel, all students follow a common interdisciplinary curriculum until the end of grade 9 , which is the last year of junior high school. The main science subjects included in the curriculum in the 3 years of junior high schools are (a) biology and chemistry including topics such as the properties of water and its importance for plants, animals and human beings, mixtures and compounds, reproduction systems in plants, animals and human beings, the cell, nutrition, food types, photosynthesis and the human digestive system, processes in ecological systems and human's dependence on the environment, heredity, genetics, DNA, chromosomes, meiosis and mitosis; (b) physics topics such as the structure, the properties, and the states of matter, mass and volume, interactions and forces, electrical current and voltage, forces between charged particles, the atom and the periodic table, energy, its transformation and conservation, forces and energy, Newton's laws; and (c) interdisciplinary topics such as ecological systems, information and communication, technological systems and its products, the Earth and the Universe. More than half of the teachers are biology teachers, about a third of them physics teachers, and very few are chemistry teachers.

In senior high school, Israeli students select a major field of study (physics, biology, and chemistry are the science fields that can be chosen) either in grade 10 or 11 , on which they are evaluated by a matriculation examination at the end of grade 12 . Tamir (1988) found that substantially more Israeli boys planned to study science-oriented fields and to choose science-oriented careers than girls. Tamir et al. (1974) already stated that:

Low enrollments in the physical sciences (are) a professional concern ... primarily because of their ad- verse effect on the general education of high school students, but also because of their possible impact on vocational choice, notably that of potential teachers. (p. 75)

Despite the aforementioned reforms, over the last 3 years, only about $10 \%$ of the students chose physics as a major field of study. During those years, $70 \%$ of the physics students were boys and only $30 \%$ girls; these figures are the same as those recorded about 25 years ago. In parallel, over the last 10 years almost the same number of students chose to major in biology; during those years, $60-66 \%$ of the biology students were girls and only $34-40 \%$ were boys. This in not the case globally: Spall et al. (2003) reported that in England and Wales physics is much less popular than biology. For example, in 2002, some 31,500 students participated in Advanced (A) level physics compared with the 52,100 who chose A level biology (Publishers' Association/Education Publishers Council, 2003). This distribution is reflected in the numbers of students going on to take physical science at university level; in 2001, there were 10,700 applications for university places in England and Wales in the physical sciences, compared with 16,000 applications for biology (Universities and Colleges Admission Service, 2003).

Overall, less than $25 \%$ of Israeli high school students major in science, including chemistry, in which there is an almost even gender distribution. This is a dramatic decline compared to the situation in the 1980 s, in which only about half of the senior high school students took no science subject as a specialized field of study (Friedler and Tamir, 1990). This 'swing away from science' was observed in several countries. In England and Wales, for instance, the percentage of students studying science, or science and mathematics only post- 16 , has declined by more than one-half from the 1980s to the early 2000s (Osborne et al., 2003).

Since only those students who take science, or science and mathematics, are able (without further remedial courses) to pursue further a scientific education and scientific careers, the decline in the number of science-based students as a proportion of all students eligible for higher education in the United States and several European countries has raised concerns about their economic future and the scientific literacy of their population (Dearing, 1996; National Commission on Mathematics and Science Teaching for the 21st Century, 2000). 


\section{THE PRESENT STUDY}

ROSE (The Relevance of Science Education) is an international comparative project that makes use of a questionnaire with items that may shed light on the questions raised in previous section.

As Sjoberg et al. (2004) stated:

\begin{abstract}
The lack of relevance of the S\&T curriculum is probably one of the greatest barriers for good learning as well as for interest in the subject. The ROSE project has the ambition to provide theoretical insight into factors that relate to the relevance of the contents as well as the contexts of S\&T curricula. ROSE intends to provide a base for informed discussions on how to improve curricula and enhance the interest in S\&T. (p. 43)
\end{abstract}

The ROSE survey was conducted in Israel in January-March 2003; international data collection was finalized by June 2004. Students responded on four-point Likert scales with categories of 'Not interested' to 'Very interested,' 'Disagree' to 'Agree,' 'Not important' to 'Very important,' and 'Never' to 'Often.' For each item, students indicated their response by marking the appropriate box, while data entry was done on a scale from 1 to 4 . The ROSE questionnaire, developed by an international advisory group of renowned researchers in science education, comprises about 250 items. To handle the amount of material and also to elevate the discussion from responses to single items to a more general level, questionnaire items were merged into composite variables or clusters; each cluster constituted one index. The indexes are latent variables not directly observed but developed from a set of observed variables (the questionnaire items). The indexes are simply average item scores; each index contains a different number of items. Combinations of theoretical perspectives, the initial ideas of the questionnaire developers, exploratory factor analysis and reliability analyses using Cronbach's $\alpha$ led to the structure of the current indexes: "What I want to learn about," "My future job," "Me and the environmental challenges," "My science classes," "My opinion about science and technology," "My out-of-school experiences," and "Me as a scientist" (the only open item). More details about the ROSE instrument, its theoretical background and development can be found in Schreiner and Sjøberg (2004).

This study included 635 Israeli students (338 females and 297 males) randomly sampled in clusters ( 25 schools, one class at each school). The sample represents the population of all Israeli 9th-grade secular Jew students. We report the results of a study dealing with students' interest in physics at the end of their compulsory studies in Israel, their opinions about their science classes, their out-ofschool experiences in physics, and their attitudes toward science and technology, carried out in the framework of the ROSE Project.

How interested are students in learning about physics topics? One index in the questionnaire is an inventory of possible topics to learn about. Students were requested to select the appropriate category for how interested they are in learning about the topic. The "Students' interest in physics" variable is a subindex of a more comprehensive one: "What I want to learn about," comprising 22 items with Cronbach's $\alpha$ coefficient of 0.88 . The "Students' opinions about their science classes" variable is also a sub-index of a more comprehensive one, "My science classes," comprising 14 items with Cronbach's $\alpha$ coefficient of 0.89 . The students' attitudes toward science and technology variable was defined a priori by the questionnaire developers and comprised 16 items with Cronbach's $\alpha$ coefficient of 0.79 . The "Students' out-of-school experience in physics" variable is a sub-index of a more comprehensive one, "My out-of-school experiences," comprising 20 items with Cronbach's $\alpha$ coefficient of 0.84 (see Appendix to characterize the different variables used in this study).

Students' overall interest in physics was "neutral" (mean $=2.5, \mathrm{SD}=0.57)$; students' attitudes toward science and technology was somewhat higher than their interest in physics (mean $=2.65, \mathrm{SD}=$ 0.43 ); their opinions about their science classes (mean $=2.19, \mathrm{SD}=0.69)$ and their out-of-school experience in physics $($ mean $=2.16, \mathrm{SD}=0.47)$ were generally low. Table I shows the difference between boys and girls for these variables.

We see that all the differences are statistically significant. Boys showed a higher interest in physics and had more out-of-school experience in physics than girls, with a large effect size (Cohen, 1988). Boys also held more positive attitudes toward science and technology and better opinions about science classes than girls, but with a smaller effect size. Sjoberg et al. (2004), in their first review of the international data, found that:

Some challenges in S\&T education seem to be common for most countries. Other challenges seem to be more pronounced in certain countries than other. For instance, the lack of interest in S\&T studies, and the possible hostility or disenchantment with S\&T seem to be more pronounced in many highly 
Table I. Comparison Between Boys and Girls

\begin{tabular}{lccccc}
\hline & & & & \multicolumn{2}{c}{$\begin{array}{c}\text { Cohen's size } \\
\text { effect }(d)\end{array}$} \\
\hline Students' interest in physics & Girls $^{a}$ & Boys $^{a}$ & $t$-test & $p$-value & 0.488 \\
Students' attitudes to S\&T & $2.37(0.55)$ & $2.64(0.56)$ & 6.13 & $<0.01$ & 0.236 \\
Students' opinions about science classes & $2.60(0.44)$ & $2.70(0.43)$ & 2.97 & $=0.03$ & 0.306 \\
Students' out-of-school experiences in physics & $2.09(0.70)$ & $2.30(0.66)$ & 3.84 & $<0.01$ & 0.685 \\
\hline
\end{tabular}

${ }^{a}$ The values are mean (SD).

developed countries than other parts of the world. The 'rich' OECD countries (US, Canada, Western Europe, Australia, Japan) seem to have such challenges, while such trends are to a less extent found in economically less developed countries of Asia, Africa, Oceania, and Latin America. (p. 44)

How is students' interest in physics related to the other three variables? We calculated the Pearson correlation coefficients between them, as can be seen in Table II.

We found a stronger correlation between students' "neutral" interest in physics and negative opinions of science classes than between more positive attitudes toward science and technology and limited out-of-school experiences in physics. Moreover, we performed a multiple regression, whose results appear in Table III.

Students' opinions of their science classes, their out-of school experiences in physics, their attitudes toward science and technology, and their gender proved to be significant factors explaining about 37\% of students' "neutral" interest in physics. (Students' opinions of their science classes contributed $27 \%$, their out-of-school experiences in physics $6 \%$, their attitudes to science and technology only $2.5 \%$, and their gender less than $1 \%$.)

We looked further and found only 133 students ( $21 \%$ of the sample) who were interested in physics, i.e., they marked on the average, that they were "interested" or "very interested" in the different physics topics presented to them in the questionnaire. The gender distribution among them was 89 boys $(67 \%)$ and 44 girls (33\%), with no statistically significant dif- ference in their interest in physics. The strongest correlation to this variable was "limited out-of-school experience in physics" with a Pearson coefficient of 0.424 ( $p$-value $<0.01$ ) and with a significant contribution of $18 \%$ to the explanation of their interest in physics in a multiple regression model. This was also the only variable, which showed a statistically significant difference between boys and girls in this group $(t=2.79, p$-value $=0.005)$, with boys having more out-of-school experiences (mean $=2.50, \mathrm{SD}=0.48$ ) than girls (mean $=2.26, \mathrm{SD}=0.43$ ).

These findings raise serious questions about the implementation of the changes made in the Israeli science curriculum in primary and junior high school, if indeed the goal is to prepare the new generation for life in a scientific-technological era, as stated by the Tomorrow 98 Report (1992).

\section{DISCUSSION}

There is an extensive literature on students' attitudes, interests and enrollments in science (Gardner, 1975; Ormerod and Duckworth, 1975; Osborne et al., 2003; Schibeci, 1984; Simpson et al., 1994). It seems natural to assert that students' interests will influence their enrolment, "since enrolling for a subject at a stage when it becomes optional is an obvious way of expressing one's interest" (Gardner and Tamir, 1989b, p. 426). As Sjoberg (1983) noted, much of what people in the industrialized world do in their daily life is probably partly governed by their interests. Ormerod and Duckworth (1975) pointed out

Table II. Pearson Correlation Coefficients

\begin{tabular}{lcccc}
\hline & $\begin{array}{c}\text { Students' interest } \\
\text { in physics }\end{array}$ & $\begin{array}{c}\text { Students' attitudes } \\
\text { to S\&T }\end{array}$ & $\begin{array}{c}\text { Students' opinions about } \\
\text { science classes }\end{array}$ & $\begin{array}{c}\text { Students' out-of-school } \\
\text { experiences in physics }\end{array}$ \\
\hline $\begin{array}{l}\text { Students' interest in physics } \\
\text { Students' attitudes to S\&T }\end{array}$ & 1.000 & $0.377(<0.01)$ & $0.520(<0.01)$ & $0.381(<0.01)$ \\
$\begin{array}{l}\text { Students' opinions about science } \\
\text { classes }\end{array}$ & - & 1.000 & $0.421(<0.01)$ & $0.189(<0.01)$ \\
$\begin{array}{l}\text { Students' out-of-school } \\
\text { experiences in physics }\end{array}$ & - & - & 1.000 & $0.300(<0.01)$ \\
\hline
\end{tabular}


Table III. Multiple Regression Model-Dependent Variable: Interest in Physics

\begin{tabular}{lcccc}
\hline \multicolumn{1}{c}{ Model } & $R$ & $R^{2}$ & Adjusted $R^{2}$ & $p$-value \\
\hline Students' opinions about science classes & 0.520 & 0.270 & 0.269 & $<0.01$ \\
Students' out-of-school experiences in physics & 0.575 & 0.331 & 0.329 & $<0.01$ \\
Students' attitudes to S\&T & 0.597 & 0.357 & 0.354 & $<0.01$ \\
Gender & 0.604 & 0.365 & 0.361 & $<0.01$ \\
\hline
\end{tabular}

that interest in science appears to be aroused at an earlier age than interest in other curriculum areas, suggesting that primary science experience might be important for future students' long-term interest in the subject. More lately, Craig and Ayres (1988) stated that British girls in most of the primary classes expressed more interest in studying further school science topics than the boys. But they added:

\begin{abstract}
The level of interest amongst the girls, which at primary school had been higher than for boys, appeared to have dropped considerably so that the girls who had greatest primary science experience now gave the lowest response to questions about interest in future school science topics. (p. 423)
\end{abstract}

In a study carried out in Germany, Haussler (1987) confirmed the general trend found in many other studies, which is that overall interest in physics decreases as students grow older and that boys are more interested than girls. However, he found that this drop in interest was rather moderate; it was most pronounced during the interval between 12 and 13 years of age, namely the age when formal instruction in physics starts, and was fairly level afterwards. A possible interpretation of this finding would be that prior to any physics instruction students have high expectations with respect to physics, which are not quite met by the kind of physics lessons they experience later in school.

Lyons (2004) reported that students' descriptions of school science generally revolved around four characteristics:

1. It was described as a subject that focused on facts transmitted from expert sourcesteachers and texts-to relatively passive recipients. Several studies have indeed revealed that while relatively negative attitudes of students are usually associated with more traditional approaches to science instruction (Lord, 1997; Shepardson and Pizzini, 1993), their perceptions of science classrooms as constructivist are correlated positively to student attitudes (Aldridge et al., 2000; Fisher and Kim, 1999).
2. Curriculum content was often presented in a decontextualized manner, leading many students to consider school science irrelevant and boring.

3. Students considered physics and chemistry to be the most difficult of science courses, and generally more difficult than most other subjects.

4. Physics and chemistry were conceptualized as subjects having a primarily strategic value, in that they would enhance the students' university and career options. Juuti et al. (2004) found that students' evaluated future relevance as the most important reason to choose or reject physics in the upper secondary school.

The phenomena that a low percentage of girls learn science and technology subjects at the high school level, and that a low number of women is found in professions related to science and technology at the academic and industrial levels, is well known around the world (Lockheed et al., 1985; NAEP, 1983). Whitten et al. (2003), for instance, reported that in 1998 in the United States, women received about $40 \%$ of the bachelor's degrees in mathematics and chemistry, but only $19 \%$ of the degrees in physics. This under-representation worsened at higher levels: the same year, women constituted $13 \%$ of physics Ph.D. recipients and $8 \%$ of physics faculty. According to the NSF, the community of working Ph.D. level physicists in 2000 was $84 \%$ White and $93 \%$ male.

In recent years, different lines of investigation have been developed, coinciding in their analysis of the causes of students' decreasing interest in the study of physics, as well as possible solutions. Similarly, changes in society and in the interrelation between science and technology, and also the disconnection between scholastic science and the reality of a scientifically oriented society, have necessitated the reestablishment of objectives in the teaching of science. The two paths have converged in a field that has been fruitful and that appears to 
Table IV. Girls' and Boys' Most Interesting Physics Topics

\begin{tabular}{lcr}
\hline \multicolumn{1}{c}{ Subject } & Girls' interest & Boys' interest \\
\hline How it feels to be weightless in space & $3.29(0.98)$ & $3.21(1.05)$ \\
How meteors, comets or asteroids may cause disasters on earth & $2.91(1.02)$ & $3.10(0.96)$ \\
Black holes, supernovas, and other spectacular objects in outer space & $2.68(1.16)$ & $3.12(1.04)$ \\
How the atom bomb functions & $2.62(1.16)$ & $3.40(0.90)$ \\
\hline
\end{tabular}

Note. The values are mean (SD).

be an effective strategy in science education. This is evinced by the enormous quantity of literature in regard to this subject (Solomon and Aikenhead, 1994) and by the development of numerous projects and studies related to the treatment of STS interactions in education. The development of the different STS projects (like the Tomorrow 98 Report) attempts to bring the teaching of science closer to the needs of the science student as a member of a society that is becoming more and more technologically developed, and to remove gender bias in subject choice by presenting more balanced science courses.

So, what is the reason why students' interest in physics at the end of junior high school is so low? What can be done to increase the number of students, especially girls, choosing physics as their major field of study in secondary school? As we have found in our study, the most influential factor on students' interest in physics is their poor opinions about science classes in junior high school. In most countries, the evidence would indicate that children enter junior high school with a highly favorable attitude toward science and interest in science, both of which are eroded by their experience of school science, particularly for girls (Kahle and Lakes, 1983). Various researchers (Hendley et al., 1995; Sundberg et al., 1994; Woolnough, 1994a) concluded that it is the quality of teaching of school science that is a significant determinant of attitude towards school science. Osborne and Collins (2000) claim that, for many, contemporary curricula put too much emphasis on undemanding activities such as recall, copying and a lack of intellectual challenge.
Considering the results obtained in the present study, we looked for the physics topics boys and girls were more interested in. We concluded that four of the five most interesting topics were shared by the two groups, as can be seen in Table IV.

Girls were also interested in "How the eye can see light and colors" (mean $=2.81, \mathrm{SD}=0.99$ ) and boys in "Rockets, satellites and space travel" $($ mean $=3.11, \mathrm{SD}=1.05)$. Most of these topics relate to astronomy and astrophysics, a similar finding to that obtained by Sjoberg $(2000 \mathrm{a}, \mathrm{b})$ among 13-yearold students. As mentioned earlier, astronomy is a subject included in the official curriculum but it is not taught in any Israeli school; without this essential ingredient of relevance, sustaining interest is then difficult, if not impossible.

We also looked for the five most positive opinions toward science and technology held by boys and girls; we found that the two groups shared all five, as seen in Table V.

We may assume that students who hold a positive opinion about science, who are fascinated by natural phenomena, and who recognize the general importance of science or the role that science may play in their future, may nevertheless not be interested in the kind of physics they encounter in the classroom. According to Osborne et al. (2003):

\footnotetext{
This disparity ... between the high-tech and socially relevant perception of science held by students and the more theoretical, decontexualized version of school science promulgated by teachers, identifies a major gulf between teachers and their students that may impede effective communication. In essence, the vision that school science offers is a
}

Table V. Girls' and Boys' Most Positive Attitudes to Science and Technology

\begin{tabular}{lcc}
\hline \multicolumn{1}{c}{ Opinion } & Girls & Boys \\
\hline S\&T will find cures for diseases such as HIV/AIDS, cancer, etc. & $3.53(0.72)$ & $3.45(0.72)$ \\
A country needs S\&T to become developed & $3.48(0.79)$ & $3.47(0.77)$ \\
Thanks to S\&T, there will be greater opportunities for future generations & $3.46(0.77)$ & $3.35(0.78)$ \\
S\&T are important for society & $3.30(0.89)$ & $3.34(0.82)$ \\
Scientific theories develop and change all the time & $3.25(0.89)$ & $3.16(0.89)$ \\
\hline
\end{tabular}

Note. The values are mean (SD). 
backward-looking view of the well-established scientific landscape, whereas, in contrast, what appeals to and excites students is the 'white heat' of the technological future offered by science. In short, to capitalize on students' interests, school science needs to be less retrospective and more prospective. (p. 1062)

According to Howes (2002), science education reforms basically ignore the very people they are intended to benefit. Physics as it is taught in the majority of physics courses does not seriously take into account students' interests. Adaptation of the curriculum by adding topics students are interested in could be a very effective means to solve some of the current problems of physics education.

As already stated by Haussler and Hoffman (2000),

The misfit between the actual curriculum and students' interest might be responsible to a great deal for the rather poor results of physics instruction. Or stating this in a more positive way, a better fit between curriculum and students' interests could lead to better results in terms of cognitive as well as affective outcomes. (p. 697)

Perhaps the strongest message that emerges from our study, and many of the studies cited earlier, is the need to concentrate on ways to develop students' affective responses so that they find personal satisfaction in doing science and thus want to continue with it. If we add to these findings, the fact mentioned earlier here in Israel and reported also in the UK (Osborne et al., 2003), that physics in junior high school is often taught by teachers who lack expert knowledge and who have little enthusiasm for the subject, the quality of teaching and learning is deprived. In such situations, teachers who lack confidence and familiarity fall back on didactic modes of teaching that increase students' reluctance. We clearly need to make the curriculum as relevant and as motivating to the students as possible, but as Woolnough (1994b) has already noted, without lively teachers, with the time and inclination to teach physics in a stimulating manner, few students will become 'switched on' to physics.

Furthermore, although Solbes and Vilches (1997) found that the absence of STS interactions in science education is a cause of lack of interest among students, most secondary school teachers in Spain (89\%) ignore these aspects when analyzing materials used routinely in physics classes. They state,

It is to be expected that, if the majority of teachers do not consider interactive STS aspects a necessary element, then they evidently do not transmit a complete and contextualized vision of science to their students. Many explain that they do not open up the discipline to daily life because of structural problems relating to their timetable (lack of time). (p. 380)

Moreover, we see that

- although girls and boys in some domains have a somewhat different interest structure, there is a considerable overlap in interest;

- girls as well as boys do not experience their physics classes as interesting;

- for both sexes, opinions about science are not a strong predictor of interest in physics as a school subject. According to Haussler and Hoffman (2000).

\begin{abstract}
The best predictor of [students' interest in physics as a school subject] is the self-concept a student has from his or her confidence in being successful in the physics class ... In comparison with their male classmates, on average girls have a physics-related selfconcept that is ill developed. (p. 872)
\end{abstract}

We also interviewed most of the school principals whose classes participated in this study. They indicated that although the curriculum was changed in accord with the recommendations of the Tomorrow 98 (1992) Report, in many junior high schools the time allocated to the science and technology classes was significantly less than that proposed by the report, 12 instead of 18 hours during the 3 years of junior high school. Secondary teachers in Spain also stated this (Solbes and Vilches, 1997). Furthermore, many teachers lack the training needed for teaching interdisciplinary subjects. If the new science and technology curriculum is to succeed so that students become more science-literate and increase their interest in physics, then these shortcomings must be taken into account and overcome.

We therefore came to the conclusion that the following changes are needed:

1. Curricular changes: Adding to the physics courses the topics that interest both girls and boys.

2. Behavioral changes: Making teachers more proficient in teaching physics in an interdisciplinary way, and by adopting constructivist approaches to instruction: supporting girls to develop a more positive physics-related self-concept. Several techniques were applied by researchers with positive effect on students' interest in physics, such as the "educational reconstruction" (Kattman et al., 
1997), or “problem posing” (Lijnse, 1995) approaches. More recently, an increase in students' interest in learning physics was reported by Seker (2005) who introduced several topics using the history of science, and by Tai and Tuan (2005) who used an inquirybased instruction providing opportunities for students to explore, manipulate, and experience how science knowledge is constructed.

3. Organizational changes: Allocating the appropriate time needed for the science and technology classes in junior high school, as proposed by the Tomorrow 98 (1992) Report.

\section{APPENDIX}

\section{Students' Interest in Physics (Cronbach's $\alpha=0.88$ )} lowing?

How interested are you in learning about the fol-

A01. Stars, planets and the universe.

A17. Atoms and molecules.

A18. How radioactivity affects the human body.

A19. Light around us that we cannot see (infrared, ultraviolet).

A21. How different musical instruments produce different sounds.

A22. Black holes, supernovas, and other spectacular objects in outer space.

A23. How meteors, comets or asteroids may cause disasters on earth.

A30. How the atom bomb functions.

A34. How it feels to be weightless in space.

A35. How to find my way and navigate by the stars.

A36. How the eye can see light and colours.

A44. Rockets, satellites and space travel.

A45. The use of satellites for communication and other purposes.

A46. How X-rays, ultrasound, etc. are used in medicine.

A48. How a nuclear power plant functions.

C02. Optical instruments and how they work (telescope, camera, microscope, etc.).

C16. Why the stars twinkle and the sky is blue.

C17. Why we can see the rainbow.

E02. How the sunset colours the sky.

E20. How energy can be saved or used in a more effective way.

E21. New sources of energy from the sun, wind, tides, waves, etc.
E27. Electricity, how it is produced and used in the home.

\section{Students' Opinions About Their Science Classes (Cronbach's $\alpha=0.89$ )}

To what extent do you agree with the following statements about the science that you may have had at school?

F02. School science is interesting.

F04. School science has opened my eyes to new and exciting jobs.

F05. I like school science better than most other subjects.

F06. I think everybody should learn science at school.

F07. The things that I learn in science at school will be helpful in my everyday life.

F08. I think that the science I learn at school will improve my career chances.

F09. School science has made me more critical and sceptical.

F10. School science has increased my curiosity about things we cannot yet explain.

F11. School science has increased my appreciation of nature.

F12. School science has shown me the importance of science for our way of living.

F13. School science has taught me how to take better care of my health.

F14. I would like to become a scientist.

F15. I would like to have as much science as possible at school.

\section{Students' Attitudes Toward Science and Technology (Cronbach's $\alpha=0.79$ )}

To what extent do you agree with the following statements?

G01. Science and technology are important for society.

G02. Science and technology will find cures to diseases such as HIV/AIDS, cancer, etc.

G03. Thanks to science and technology, there will be greater opportunities for future generations.

G04. Science and technology make our lives healthier, easier and more comfortable.

G05. New technologies will make work more interesting. 
G06. The benefits of science are greater than the harmful effects it could have.

G07. Science and technology will help to eradicate poverty and famine in the world.

G08. Science and technology can solve nearly all problems.

G09. Science and technology are helping the poor.

G10. Science and technology are the cause of the environmental problems.

G11. A country needs science and technology to become developed.

G12. Science and technology benefit mainly the developed countries.

G13. Scientists follow the scientific method that always leads them to correct answers.

G14. We should always trust what scientists have to say.

G15. Scientists are neutral and objective.

G16. Scientific theories develop and change all the time.

\section{Students' Out-Of-School Experiences in Physics (Cronbach's $\alpha=0.84$ )}

How often have you done this outside school?

H01. Tried to find the star constellations in the sky.

H04. Used a compass to find direction.

H09. Visited a science centre or science museum.

$\mathrm{H} 13$. Watched nature programmes on TV or in a cinema.

H26. Seen an X-ray of a part of my body.

H30. Used binoculars.

H31. Used a camera.

H32. Made a bow and arrow, slingshot, catapult, or boomerang.

H33. Used an air gun or rifle.

H34. Used a water pump or siphon.

H35. Made a model such as toy plane or boat, etc.

H36. Used a science kit (like for chemistry, optics or electricity)

H37. Used a windmill, watermill, waterwheel, etc.

H39. Changed or fixed electric bulbs or fuses.

H40. Connected an electric lead to a plug, etc.

H41. Used a stopwatch.

H42. Measured the temperature with a thermometer.

H55. Walked while balancing an object on my head.

H58. Used a rope and pulley for lifting heavy things.

H61. Charged a car battery.

\section{REFERENCES}

Aldridge, J., Fraser, B., Taylor, P., and Chen, C. (2000). Constructivist learning environments in a cross-national study in Taiwan and Australia. International Journal of Science Education 22: 37-55.

American Association for the Advancement of Science (1990). Science for all Americans, Oxford University Press, New York.

Baker, M., and Doran, R. (1975). From an awareness of scientific data to concerns of mankind: Strategies for affective instruction in science. Science Education 59: 539-558.

Bordt, M., DeBroucker, P., Read, C., Harris, S., and Zhang, Y. (2001). Determinants of science and technology skills: Overview of the study. Education Quarterly Review, Statistics Canada 1: 8-11.

Catsambis, S. (1995). Gender, race, ethnicity, and science education in middle grades. Journal of Research in Science Teaching 32: 243-257.

Cohen, J. (1988). Statistical Power Analysis for the Behavioral Sciences, Erlbaum, Hillsdale, NJ.

Commission of European Communities (2001). The Concrete Future Objectives of Education Systems: Final Report from the Commission (COM 2001/59).

Craig, J., and Ayres, D. (1988). Does primary science affect girls' and boys' interest in secondary science? School Science Review 69: 417-426.

Dearing, R. (1996). Review of Qualifications for 16-19 Year Olds, Schools Curriculum and Assessment Authority, London.

Dekkers, J., and DeLaeter, J. (2001). Enrolments trends in school science education in Australia. International Journal of Science Education 23: 487-500.

Fisher, D., and Kim, H. (1999). Constructivist Learning Environments in Science Classes in Korea. Paper presented at the $\mathrm{An}$ nual Meeting of AERA, Montreal, Canada.

Francis, L., and Greer, J. (1999). Measuring attitudes towards science among secondary school students: The affective domain. Journal of Research in Science Teaching 35: 877896.

Friedler, Y., and Tamir, P. (1990). Sex differences in science education in Israel: An analysis of 15 years of research. Research in Science \& Technological Education 8: 21-34.

Gardner, P. (1974). Sex differences in achievements, attitudes and personality of science students: A review. Paper presented at the Fifth Annual Meeting of the Australian Science Education Research Association.

Gardner, P. (1975). Attitudes to science: A review. Studies in Science Education 2: 1-41.

Gardner, P. (1985). Students' attitudes to science and technology: An international overview. In Lehrke, M., Hoffman, L., and Gardner, P. (Eds.), Interests in Science and Technology Education, Kiel, 12th IPN Symposium, IPN, Schriftenreihe 102, pp. 15-34.

Gardner, P. (1998). The development of males' and females' interests in science and technology. In Hoffman, L., Krapp, A., Renninger, K., and Baumert, J. (Eds.), Interest and Learning, Proceedings of the Second Conference on Interest and Gender, Kiel, IPN, pp. 41-57.

Gardner, P., and Tamir, P. (1989a). Interest in Biology. Part I: A multidimensional construct. Journal of Research in Science Teaching 26: 409-423.

Gardner, P., and Tamir, P. (1989b). Interest in Biology. Part II: Relationship with the enrollment intentions of Israeli senior high school biology students. Journal of Research in Science Teaching 26: 425-433.

Garg, K., and Gupta, B. (2003). Decline in science education in India: A case study at +2 and undergraduate level. Current Science 84: 1198-1201. 
Goto, M. (2001). 'Japan,' in International Bureau for Education, Science Education for Contemporary Society: Problems, Issues and Dilemmas, Geneva, IBE, Unesco, pp. 31-38.

Graber, W. (1993). Pupils' interest in chemistry and chemistry lessons. In Proceedings of the International Conference Science Education in Developing Countries: From Theory to Practice, Jerusalem, Israel, p. 201.

Haussler, P. (1987). Measuring students' interest in physics: Design and results of a cross-sectional study in the Federal Republic of Germany. International Journal of Science Education 9: 79-92.

Haussler, P., and Hoffman, L. (2000). An intervention study to enhance girls' interest, self-concept, and achievement in physics classes. Journal of Research in Science Teaching 39: 870888.

Hendley, D., Parkinson, J., Stables, A., and Tanner, H. (1995). Gender differences in pupil attitudes to the national curriculum foundation subjects of English, mathematics, science and technology in Key Stage 3 in South Wales. Educational Studies 21: 85-97.

Hidi, S., and Andersen, V. (1992). Situational interest and its impact on reading and expository writing. In Renninger, K., and Hidi, S. (Eds.), The Role of Interest in Learning and Development, Erlbaum, Hillsdale, NJ, pp. 215-238.

Hoffman, L. (2002). Promoting girls' interest and achievement in physics classes for beginners. Learning and Instruction 12: 447-465.

Howes, E. (2002). Connecting Girls and Science: Constructivism, Feminism and Science Education Reform, Teachers College Press, New York.

Jones, G., Howe, A., and Rua, M. (2000). Gender differences in students' experiences, interests, and attitudes towards science and scientists. Science Education 84: 180-192.

Juuti, K., Lavonen, J., Uitto, A., Byman, R., and Meisalo, V. (2004). Students' reasons to choose or reject physics. Paper presented at the GIREP Conference, Ostrava, Czech Republic.

Kahle, J., and Lakes, M. (1983). The myth of equality in science classrooms. Journal of Research in Science Teaching 20: 131140.

Kahle, J., and Meece, J. (1994). Research on gender issues in the classroom. In Gabel, D. (Ed.), Handbook of Research on Science Teaching and Learning, Macmillan, New York, pp. 542557.

Kattman, U., Duit, R., Gropengie $\beta$ er, H., and Komorek, M. (1997). The model of educational reconstruction. A model for science education research and development. Zeitschrift für Didaktik der Naturwissenschaften 3: 3-18.

Lijnse, P. (1995). 'Developmental research' as a way to an empirical based 'didactical structure' of science. Science Education 79: 189-199.

Lockheed, E., Thorpe, M., Brooks-Gun, J., Casserly, P., and McAlloon, A. (1985). Sex and Ethnic Differences in Middle School Mathematics Science and Computer Science: What Do We Know? Report submitted to the Ford Foundation, Education Testing Service, Princeton, New Jersey.

Lord, T. (1997). A comparison between traditional and constructivist teaching in college biology. Innovative Higher Education 21: $197-216$

Lyons, T. (2004). Choosing physical science courses: The importance of cultural and social capital in the enrolment decisions of high achieving students. Paper presented at the XI IOSTE Symposium, Lublin, Poland.

Menis, J. (1983). Attitudes towards chemistry as compared with those towards mathematics among tenth grade pupils (aged $15)$ in high level secondary schools in Israel. Research in Science and Technological Education 1: 185-191.

NAEP [National Assessment of Educational Progress] (1983). Third National Mathematics Assessment: Results, Trends and
Issues, NAEP Report No. 13-MA-01. Education Testing Service, Princeton, New Jersey.

National Commission on Mathematics and Science Teaching for the 21st Century (2000). Before it's too late, US Department of Education, Washington, DC.

National Science Foundation (2002). Science and Engineering Indicators 2002, online at http://www.nsf.gov/sbe/srs/ seind02/c0/c0s1.htm (accessed March 4, 2004).

Oh, P. S., and Yager, R. (2004). Development of constructivist science classrooms and changes in student attitudes toward science learning. Science Education International 15: 105113.

Ormerod, M., and Duckworth, D. (1975). Pupils' Attitudes to Science, Slough, National Foundation for Educational Research.

Osborne, J., and Collins, S. (2000). Pupils' and Parents' Views of the School Science Curriculum, King's College, London.

Osborne, J., Simon, S., and Collins, S. (2003). Attitudes towards science: A review of the literature and its implications. International Journal of Science Education 25: 1049-1079.

Publishers' Association/Education Publishers Council (2003). UK School-Market dataset: A level entries 1995-2002, online at: http://www.statisticsforbusiness.co.uk/epcdata (accessed April 15, 2004).

Schibeci, R. (1984). Attitudes to science: An update. Studies in Science Education 11: 26-59.

Schreiner, C., and Sjøberg, S. (2004). Sowing the Seeds of ROSE. Background, Rationale, Questionnaire Development and Data Collection for ROSE (The Relevance of Science Education - - A Comparative Study of Students' Views of Science and Science Education (Acta Didactica 4/2004), Department of Teacher Education and School Development, University of Oslo, Norway.

Seker, H. (2005). The effects of using history of science on students' interest in learning science. Paper presented at the 5th Biannual Conference of ESERA, Barcelona, Spain.

Selim, M., and Shrigley, R. (1983). The group-dynamics approach: A socio-psychological approach for testing the effect of discovery and expository teaching on the science achievement and attitude of young Egyptian students. Journal of Research in Science Teaching 20: 213-224.

Shemesh, M. (1990). Gender related differences in reasoning skills and learning interests of junior high school students. Journal of Research in Science Teaching 27: 27-34.

Shepardson, D., and Pizzini, E. (1993). A comparison of student perceptions of science activities within three instructional approaches. School Science and Mathematics 93: 127131.

Shulman, R., and Tamir, P. (1973). Research on teaching in the national science. In Travers, R. (Ed.), Second Handbook of Research on Teaching, Rand McNally, Chicago.

Simpson, R., Koballa, T., Jr., Oliver, J., and Crawley, F., III (1994). Research on the affective dimension of science learning. In Gabel, D. (Ed.), Handbook of Research on Science Teaching and Learning, Macmillan, New York, pp. 211-234.

Simpson, R., and Oliver, J. (1990). A summary of major influences on attitude toward and achievement in science among adolescent students. Science Education 74: 1-18.

Sjoberg, L. (1983). Interest, achievement and vocational choice. European Journal of Science Education 5: 299-307.

Sjoberg, S. (2000a). Interesting all children in 'science for all.' In: Millar, R., Leach, J., and Osborne, J. (Eds.), Improving Science Education, Open University Press, Buckingham, pp. $165-186$.

Sjoberg, S. (2000b). Science and Scientists: The SAS Study, online at http://folk.uio.no/sveinsj/SASweb.htm (accessed April 23, 2004).

Sjoberg, S. (2002). Science for the children? Department of Teacher Education and School Department, University of Oslo. 
Sjoberg, S., Schreiner, C., and Stefansson, K. (2004). The voice of the learners. International perspectives on S\&T based on the ROSE project. In Proceedings of the XIth Symposium of IOSTE: Science and Technology Education for a Diverse World-Dilemmas, Needs and Partnerships, Lublin, Poland, pp. 43-44.

Smithers, A., and Robinson, P. (1988). The Growth of Mixed ALevels, Department of Education, University of Manchester.

Solbes, J., and Vilches, A. (1997). STS interactions and the teaching of physics and chemistry. Science Education 81: 377386.

Solomon, J., and Aikenhead, G. (Eds.) (1994). STS Education: International Perspectives on Reform, Teachers College Press, New York.

Spall, K., Barrett, S., Stanisstreet, M., Dickson, D., and Boyes, E. (2003). Undergraduates' views about biology and physics. Research in Science and Technological Education 21: 193208.

Sundberg, M., Dini, M., and Li, E. (1994). Decreasing course content improves student comprehension of science and attitudes toward science among adolescent students. Journal of Research in Science Teaching 31: 679-693.

Tai, C.-C., and Tuan, H.-L. (2005). Investigating the impact of inquiry vs. textbook instruction on 8th graders' motivation towards learning science. Paper presented at the 5th Biannual Conference of ESERA, Barcelona, Spain.
Tamir, P. (1988). Gender differences in high school science in Israel. British Educational Research Journal 14: 127-140.

Tamir, P., Arzi, A., and Zloto, D. (1974). Attitudes of Israeli high school students towards physics. Science Education 58: 75-86.

Tamir, P., Levine, T., Lewy, A., Chen, D., and Zuzovsky, R (1988). Science Teaching in Israel in the Eighties, Israel Science Teaching Center, Hebrew University, Jerusalem.

Tomorrow 98 (1992). Report from the Commission on Science and Technological Education, Ministry of Education, Jerusalem.

Universities and Colleges Admissions Service (2003). Statistical Enquiry Service, online at http://www.ucas.co.uk/figures/enq (accessed April 15, 2004).

U.S. Department of Education (1997). Findings from the condition of education 1997: No. 11: Women in mathematics and science, NCES Publication No. 97-982, U.S. Government Printing Office, Washington, DC

Weinburgh, M. (1995). Gender differences in student attitudes toward science: A meta-analysis of the literature from 1970 to 1991. Journal of Research in Science Teaching 32: 387398.

Whitten, B., Foster, S., and Duncombe, M. (2003). What works for women in undergraduate physics? Physics Today 56: 46-51.

Woolnough, B. (1994a). Effective Science Teaching, Open University Press, Buckingham.

Woolnough, B. (1994b). Why students choose physics, or reject it. Physics Education 29: 368-374. 